Research Paper

\title{
The Diagnostic Value of D-dimer, Procalcitonin and CRP in Acute Appendicitis
}

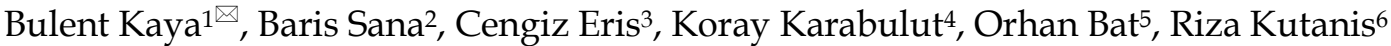 \\ 1. Department of General Surgery, Haydarpasa Numune Training and Research Hospital, Istanbul-Turkey. \\ 2. Department of General Surgery, Bagcilar Training and Research Hospital, Istanbul-Turkey. \\ 3. Department of General Surgery, Haydarpasa Numune Training and Research Hospital, Istanbul-Turkey. \\ 4. Department of General Surgery, Firat University Medical Faculty, Elazig-Turkey. \\ 5. Department of General Surgery, FSM Training and Research Hospital, Istanbul-Turkey \\ 6. Department of General Surgery, Bagcilar Training and Research Hospital, Istanbul-Turkey.
}

$\triangle$ Corresponding author: Bulent Kaya, Haydarpasa Numune Training and Research Hospital, Istanbul Turkey. Tel: +905056822101 e-mail: drbkaya@yahoo.com.

(C) Ivyspring International Publisher. This is an open-access article distributed under the terms of the Creative Commons License (http://creativecommons.org/ licenses/by-nc-nd/3.0/). Reproduction is permitted for personal, noncommercial use, provided that the article is in whole, unmodified, and properly cited.

Received: 2012.06.13; Accepted: 2012.10.25; Published: 2012.11.13

\begin{abstract}
BACKGROUND: The early diagnosis of acute abdomen is of great importance. To date, several inflammatory markers have been used for the diagnosis of acute abdominal conditions, including acute appendicitis. The aim of this study was to evaluate the diagnostic utility of D-dimer, Procalcitonin (PCT) and C-reactive protein (CRP) measurements in the acute appendicitis.

METHODS: This prospective study was conducted between March $\mathrm{I}^{\text {st }}, 2010$ and July $\mathrm{I}^{\text {st }}$, 20II. In this period, seventy-eight patients were operated with the diagnosis of acute appendicitis, and D-dimer, PCT and CRP levels of the patients were measured. The patients were grouped as phlegmonous appendicitis (Group I), gangrenous appendicitis (Group 2), perforated appendicitis (Group 3) and negative appendectomy (Group 4) according to the surgical findings and histopathological results.

RESULTS: Of 78 patients, 54 (69.2\%) were male and 24 (30.8\%) were female, and the mean age was $25.4 \pm$ I I.I years (range, I 8 to 69 years). 66 (84.6\%) patients had increased leukocyte count (white blood cell count). The PCT values were higher than the upper normal limit in 20 (25.6\%) patients, followed by D-dimer in 22 (28.2 \%) patients and CRP in 54 (69.2\%) patients. The diagnostic value of leukocyte count and CRP in acute appendicitis was higher than that of the other markers, whereas leukocyte count showed very low specificity. CRP values were higher in perforated appendicitis when compared with the phlegmonous appendicitis $(p<0.05)$. However, PCT and D-dimer showed lower diagnostic values $(26 \%$ and $31 \%$, respectively).

CONCLUSION: An increase in CRP levels alone is not sufficient to make the diagnosis of acute appendicitis. However, CRP levels may differentiate between phlegmonous appendicitis and perforated appendicitis. Due to their low sensitivity and diagnostic value, PCT and D-dimer are not better markers than CRP for the diagnosis of acute appendicitis.
\end{abstract}

Key words: Appendicitis, D-dimer, Procalcitonin, C-reactive protein.

\section{Background}

The early diagnosis of the acute abdomen is a major goal in surgical practice. Despite the introduction of novel imaging modalities, acute abdominal conditions are still a challenging problem. To date, many inflammatory markers have been used for the diagnosis of acute surgical conditions, including acute appendicitis. Leukocyte count and C-reactive protein 
(CRP) are the most commonly used laboratory tests. Procalcitonin (PCT) and D-dimer have been studied as novel biomarkers for the diagnosis of acute abdomen in recent years [1].

PCT, inactive precursor of calcitonin, is a 116 amino acid polypeptide glycoprotein with a molecular weight of $13 \mathrm{kDa}$ [2]. It is found only in the C cells of the thyroid gland under normal metabolic conditions. Assicot has first reported the increased PCT levels in patients with bacterial and fungal infections and sepsis [3]. Thereafter, many studies have confirmed that PCT is a biomarker of inflammatory host response to microbial infections and increased in surgical pathologies such as ileus and pancreatitis $[4,5]$. There is also a proportional increase in PCT levels with the severity of the infection.

D-dimer is a degradation product of fibrin dissolution. Local fibrin formation and lysis are common events during inflammatory response. In general, the elevation of D-dimer levels is not a specific response. It is most commonly used in the diagnosis of venous thromboembolism and pulmonary embolism. Recently, D-dimer has also been used as a diagnostic marker in the acute abdomen.

CRP was first identified in 1930 by Tillet and Francis. It is a non-specific acute phase reactant [6] and mainly stimulates the cell-mediated immunity and chemotaxis in inflammation. CRP levels increase in acute appendicitis in relation with the severity of infection $[7,8]$.

The aim of this prospective study was to evaluate the diagnostic value of D-dimer, PCT and CRP measurements in the acute appendicitis.

\section{Methods}

This prospective study enrolled 78 consecutive patients who were operated with the diagnosis of acute appendicitis between March 1st, 2010 and July 1st, 2011. The informed consent of the patients was obtained. The study was conducted in accordance with the Helsinki Declaration. The patients using warfarin or heparin, with a pregnancy, and under antibiotherapy were excluded from the study. The diagnosis of acute appendicitis was established based on the clinical findings of acute abdomen, routine laboratory tests and abdominal ultrasonography or computed tomography.

Blood samples were taken immediately after admission for measuring PCT, D-dimer and CRP levels. PCT levels were measured by a PCT kit (VIDAS®BRAHMS PCT- France). A PCT level of $>0.05 \mathrm{ng} / \mathrm{ml}$ was considered abnormal. D-dimer levels were measured by Stratus ${ }^{\circledR}$ CS Acute Care ${ }^{\text {TM }}$ D-dimer method. It is a two-site sandwich assay based upon solid phase Radial Partition Immunoassay (RPIA) technology. The normal range of D-dimer levels is between 0 and $600 \mathrm{ng} / \mathrm{ml}$. CRP levels were measured by a nephelometric method. The normal range of CRP levels is between 0 and $0.8 \mathrm{mg} / \mathrm{dl}$. PCT, D-dimer and CRP levels were compared between the patients in the study. Leukocyte count was also studied as a non-specific marker of the inflammation. The normal range of leukocyte count is between 4.6 and $10.2 \mathrm{~K} / \mathrm{uL}$.

All appendectomies were performed by conventional surgery and the specimens were sent for routine histopathological examination. The patients were grouped as phlegmonous appendicitis (Group 1), gangrenous appendicitis (Group 2), perforated appendicitis (Group 3) and negative appendectomy (Group 4) according to the surgical findings and histopathological results.

\section{Statistical Evaluations}

The data were presented as mean \pm SEM (standard error of mean) or median and interquartile range. The clinical and demographic variables were compared using the student-t test for continuous variables with a normal distribution, the Wilcoxon rank sum test for nonparametric variables and the chi-square test (or Fisher's exact test) for categorical variables.

\section{Results}

Of 78 patients, 54 (69.2\%) were male and 24 (30.8 $\%)$ were female, and the mean age was $25.4 \pm 11.1$ years (range, 18 to 69 years). The most common symptom was abdominal pain with an occurrence in $64(82 \%)$ patients. Right lower quadrant tenderness was the most common sign with an occurrence in 71 patients, followed by rebound tenderness in 64 patients and defense during physical examination in 19 patients. The demographic findings are shown in (Table 1). There were 47 patients (60.3\%) with phlegmonous appendicitis (Group 1), 19 patients (24.3\%) with gangrenous appendicitis (Group 2), 8 patients $(10.2 \%)$ with perforated appendicitis (Group 3 ) and 4 patients $(5.2 \%)$ with normal appendix (Group 4) 66 (84.6\%) patients had increased leukocyte count. The PCT values were higher than the upper normal limit in $20(25.6 \%)$ patients, followed by D-dimer in $22(28.2 \%)$ patients and CRP in $54(69.2 \%)$ patients. The mean values for leukocyte, PCT, D-dimer and CRP are shown in (Table 2).

CRP levels were increased in all patients with perforated appendicitis. The mean age and duration of pain were statistically higher in perforated appendicitis (Group 3) when compared with the phlegmonous, uncomplicated appendicitis (Group 1) 
$(p<0.05)$. PCT and CRP levels were also higher in perforated group $(p<0.05)$ (Table 3). CRP levels were found to be significantly different between the phlegmonous group and the perforated group $(p<0.05)$. The ROC curve for PCT (with a cut off value of $0.05 \mathrm{ng} / \mathrm{ml}$ ) was not helpful for differentiating between phlegmonous and negative appendicitis $(p>0.05)$. In addition, D-dimer (with a cut off value of $600 \mathrm{ng} / \mathrm{ml}$ ) was also not helpful for differentiating between phlegmonous and negative appendicitis $(p>0.05)$. However, CRP (with cut off value of $0.8 \mathrm{mg} / \mathrm{ml}$ ) was found to be helpful for differentiating between phlegmonous and negative appendicitis $(p<0.05)$. Sensitivity, specificity, positive and negative predictive values and diagnostic value of inflammatory markers are shown in Table 4 and Figures 1 and 2. Accordingly, leukocyte count and CRP showed the highest diagnostic value.

However, leukocyte count showed a very low specificity, and the diagnostic value of PCT and D-dimer were found to be very low $(26 \%$ and $31 \%$, respectively) for detecting acute appendicitis. ROC curves of the diagnostic value of PCT, D-dimer and $\mathrm{CRP}$ in differentiating between phlegmonous and perforated appendicitis were shown in Figures 3, 4 and 5.

Table I. General characteristics of patients operated with the diagnosis of acute appendicitis.

\begin{tabular}{|c|c|c|c|c|}
\hline & $\begin{array}{l}\text { Phlegmonous } \\
\text { Appendicitis }(n=47)\end{array}$ & $\begin{array}{l}\text { Gangrenous } \\
\text { Appendicitis }(n=19)\end{array}$ & $\begin{array}{l}\text { Perforated } \\
\text { Appendicitis }(n=8)\end{array}$ & $\begin{array}{l}\text { Negative } \\
\text { Appendectomy }(n=4)\end{array}$ \\
\hline Age (year) & $24 \pm 1$ & $25 \pm 2$ & $37 \pm 6$ & $22 \pm 7$ \\
\hline \multicolumn{5}{|l|}{ Sex } \\
\hline Female & 17 & 3 & 1 & 3 \\
\hline Male & 30 & 16 & 7 & 1 \\
\hline \multicolumn{5}{|l|}{ Physical examination } \\
\hline Tenderness in RLQ & 42 & 17 & 8 & 4 \\
\hline Rebound tenderness & 37 & 16 & 8 & 3 \\
\hline Defense & 8 & 7 & 4 & - \\
\hline \multicolumn{5}{|c|}{ Duration of abdominal pain (day) } \\
\hline$>1$ day & 3 & 5 & 5 & 2 \\
\hline$\leq 1$ day & 44 & 14 & 3 & 2 \\
\hline
\end{tabular}

Table 2. Laboratory values of WBC, D-Dimer, PCT and CRP.

\begin{tabular}{|c|c|c|c|c|}
\hline & $\begin{array}{l}\text { Phlegmonous Appendicitis } \\
(\mathrm{n}=47)\end{array}$ & $\begin{array}{l}\text { Gangrenous Appendicitis } \\
(\mathrm{n}=19)\end{array}$ & $\begin{array}{l}\text { Perforated Appendicitis } \\
(\mathrm{n}=8)\end{array}$ & $\begin{array}{l}\text { Negative Appendectomy } \\
(\mathrm{n}=4)\end{array}$ \\
\hline WBC (4.6-10.2 K/uL) & $13.5 \pm 0.5$ & $14.3 \pm 0.6$ & $17.4 \pm 1.3$ & $11.8 \pm 1.1$ \\
\hline Normal & 10 & 1 & 0 & 1 \\
\hline High & 37 & 18 & 8 & 3 \\
\hline D-dimer $(0-600 \mathrm{ng} / \mathrm{ml})$ & $424 \pm 69$ & $722 \pm 258$ & $1345 \pm 605$ & $495 \pm 319$ \\
\hline Normal & 36 & 13 & 4 & 3 \\
\hline High & 11 & 6 & 4 & 1 \\
\hline PCT $(<0.05 \mathrm{ng} / \mathrm{ml})$ & $0.29 \pm 1.8$ & $0.49 \pm 1.4$ & $3.55 \pm 8.81$ & $0.04 \pm 0.02$ \\
\hline Normal & 41 & 11 & 4 & 2 \\
\hline High & 6 & 8 & 4 & 2 \\
\hline CRP (<0.8 mg/dl) & $6.84 \pm 10.5$ & $57.14 \pm 105.7$ & $33.45 \pm 64.5$ & $3.54 \pm 6.37$ \\
\hline Normal & 18 & 3 & 0 & 3 \\
\hline High & 29 & 16 & 8 & 1 \\
\hline
\end{tabular}


Table 3. Comparison of phlegmonous and perforated appendicitis.

\begin{tabular}{llll}
\hline & Phlegmonous Appendicitis $(\mathrm{n}=47)$ & Perforated Appendicitis $(\mathrm{n}=8)$ & P value \\
\hline WBC (4.6-10.2 K/uL) & $13.5 \pm 0.5$ & $17.4 \pm 1.3$ & $0.01^{*}$ \\
Normal & 10 & 0 \\
High & 37 & 8 \\
D-dimer (0-600 ng/ml) & $424 \pm 69$ & $1345 \pm 605$ & $0.2^{*}$ \\
Normal & 36 & 4 \\
High & 11 & 4 \\
PCT $(<0.05 \mathbf{~ g / m l ) ~}$ & $0.49 \pm 1.4$ & $3.55 \pm 8.81$ \\
Normal & 41 & 4 \\
High & 6 & 4 \\
CRP $(<0.8 \mathbf{~ m g / d l ) ~}$ & $6.84 \pm 10.5$ & $33.45 \pm 64.5$ \\
Normal & 18 & 0 \\
High & 29 & 8 \\
\hline
\end{tabular}

Table 4. PPV, NPV and DV of inflammatory markers in acute appendicitis.

\begin{tabular}{llll}
\hline Laboratory results & PPV & NPV & DV \\
\hline WBC $(>10.2 \mathrm{~K} / \mathrm{ul})$ & 0.95 & 0.08 & 0.82 \\
D-Dimer $(>600 \mathrm{ng} / \mathrm{ml})$ & 0.95 & 0.05 & 0.31 \\
PCT $(>0.05 \mathrm{ng} / \mathrm{ml})$ & 0.90 & 0.03 & 0.26 \\
CRP $(>0.8 \mathrm{mg} / \mathrm{dl})$ & 0.98 & 0.13 & 0.72 \\
\hline
\end{tabular}

*PPV: Positive predictive value, NPV: Negative predictive value, DV: Diagnostic value

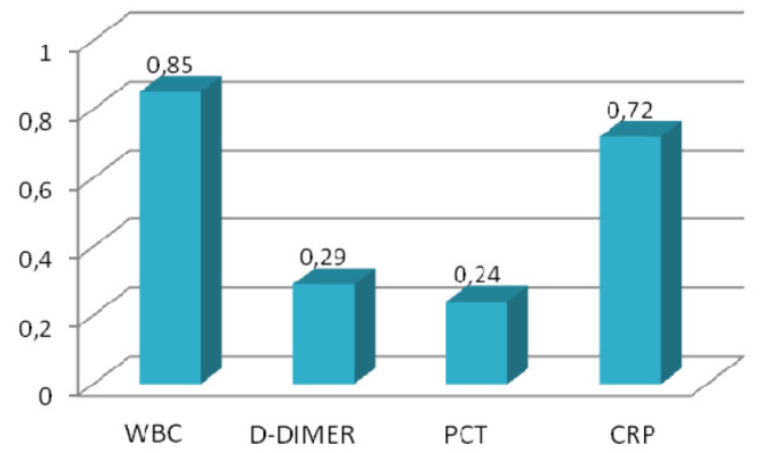

Figure I. Sensitivity values of inflammatory markers.

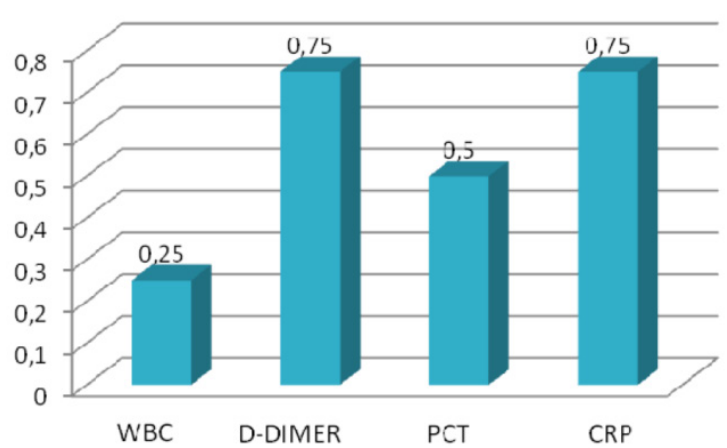

Figure 2. Specificity values of inflammatory markers.

\section{PROCALCITONIN}

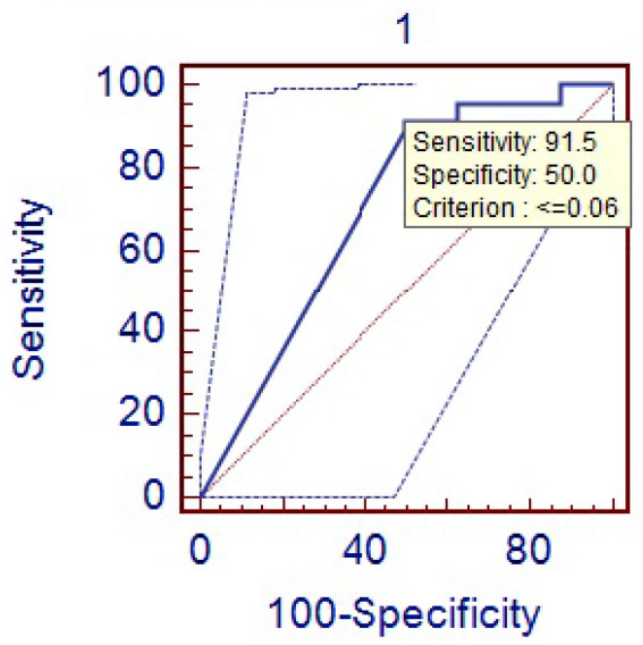

Figure 3. Comparison of phlegmenous and perforated appendectomy group ROC curve for PCT (cut off value<=0.06). 


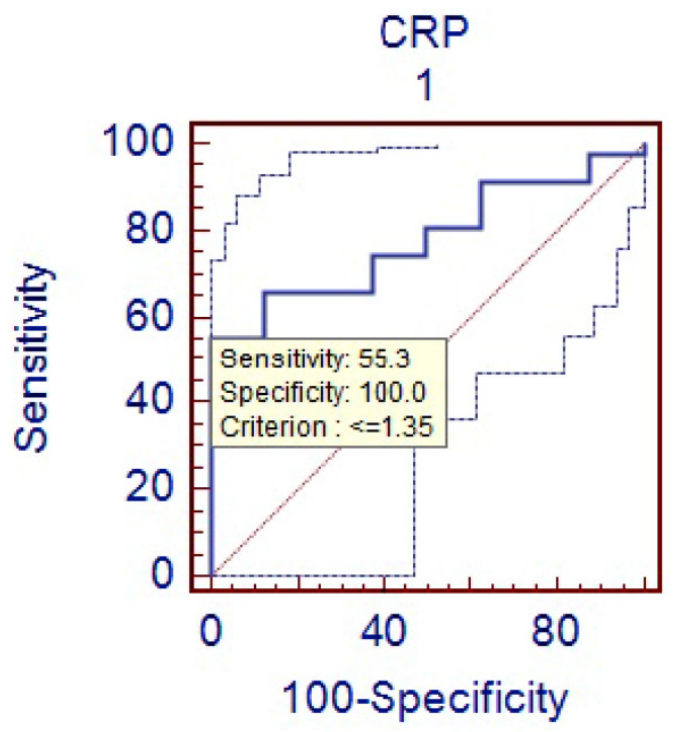

Figure 4. Comparison of phlegmenous and perforated group ROC curve for CRP (cut off value $<=1.35$ ).

\section{D- DIMER}

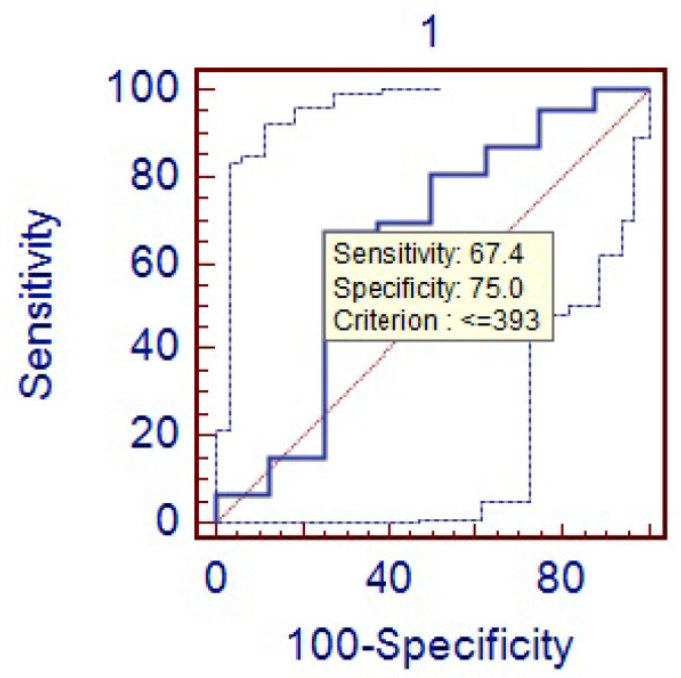

Figure 5. Comparison of phlegmenous and perforated group ROC curve for D-dimer (cut of value<=393).

\section{Discussion}

Despite the introduction of novel diagnostic tools in recent years, the diagnosis of appendicitis is still an important problem. Acute appendicitis may be associated with the perforation and serious complications. Misdiagnosis of acute appendicitis can result in unnecessary laparotomies. A 9 to $20 \%$ negative appendectomy rate has been reported in literature $[9,10,11]$.

Leukocyte count and CRP are the most frequently used laboratory tests for diagnosis of acute appendicitis. They are easily implemented in routine practice and have an advantage of cost effectiveness, but their sensitivity and specificity are limited [12]. Although it was not the major objective of this study, the sensitivity and specificity of leukocyte count were found to be $85 \%$ and $25 \%$, respectively. The low specificity value of leukocyte count seems to be an important problem. Many inflammatory markers, including phospholipase A2, serum amyloid A, interleukins and cytokines have been used to increase diagnostic accuracy in acute appendicitis $[13,14,15]$. PCT and D-dimer are new inflammatory markers, which are increased in septic conditions and also used in diagnosing acute appendicitis. It was postulated that PCT might be a better marker for bacterial sepsis [16]. Sand $M$ et al studied the diagnostic value of PCT in acute appendicitis [17]. They were concluded that PCT was specially increased in patients with appendiceal perforation and gangrenous appendicitis. But it has a very low sensitivity, which prohibits its routine use for the diagnosis of acute appendicitis. Kouame DB has also reported similar results and stated that PCT had a sensitivity of $28 \%$ in acute appendicitis [18]. In our study, the sensitivity and specificity, and the diagnostic value of PCT were $24 \%, 50 \%$, and 26 $\%$, respectively. These results showed that PCT was not a useful marker for the diagnosis of the acute appendicitis.

On the other hand, this study also demonstrated that PCT was significantly increased in patients with perforated appendicitis. PCT level was statistically higher in Group 3 (perforated appendicitis) when compared to Group 1 (phlegmonous appendicitis) $(\mathrm{p}<0.05)$.

PCT levels have been found to be lower in acute appendicitis compared to the other bacterial infections. In addition, it was claimed that uncomplicated appendicitis does not cause significant bacterial translocation [19], which may explain the low levels of PCT in uncomplicated, phlegmonous appendicitis.

D-dimer is the degradation product of fibrin dissolution. D-dimer levels may be increased in many conditions, including venous thromboembolism, acute coronary syndromes, trauma, and malignancies [20-24]. In recent years, D-dimer has been investigated in terms of acute abdominal conditions. Kurt Y et al [25] studied the diagnostic value of D-dimer for acute mesenteric ischemia in rats. They stated that D-dimer may be a valuable diagnostic tool in acute mesenteric ischemia. On the other hand, the results of other clinical studies on different acute abdominal conditions including acute appendicitis are controversial. Akyildiz $H K$ et al [26] studied the D-dimer in non-traumatic acute abdominal conditions. In their 
study, the sensitivity of D-dimer test in patients needing urgent laparotomy was found as $95.7 \%$. The sensitivity of leukocyte count was $74.8 \%$ in the same patients. They concluded that D-dimer can be an alternative to leukocyte count in diagnosing the acute abdomen. In addition, the sensitivity of D-dimer was estimated to be $29 \%$ in our study. Mentes O et al [27] have reported the similar results for the diagnostic value of $\mathrm{D}$-dimer. We found that specificity of D-dimer test in acute appendicitis was relatively higher (about 75\%). But similarly with PCT, the diagnostic value of D-dimer was very low $(31 \%)$ in the acute appendicitis. We think that the low sensitivity and diagnostic value of D-dimer is an important hindrance for its routine use as a diagnostic marker in acute appendicitis. CRP is often used to guide the clinical evaluation of the acute appendicitis. It is an acute phase reactant that synthesized in liver in response to the tissue injury. The measurement of CRP is practical, easily applicable and cost effective. The previous studies have demonstrated a sensitivity of 40 to $94 \%$ and a specificity of 38 to $87 \%$ for CRP measurement [28-30]. In this study, the sensitivity of CRP measurement was found to be $72 \%$ and the specificity was $75 \%$. Hallan S reported in a meta-analysis that CRP had moderate accuracy in diagnosing acute appendicitis [31]. When compared to other two inflammatory markers (PCT and D-dimer), CRP was found to have higher sensitivity and diagnostic accuracy for the acute appendicitis. Some authors have claimed that CRP could predict the severity of appendicitis and perforation [32-33]. We have also obtain similar results showing that CRP levels were significantly higher in perforated appendicitis cases than non-perforated cases $(\mathrm{p}<0.05)$.

\section{Conclusion}

Although this study has some limitations, such as having a small sample size for negative appendicitis, we can conclude that CRP seems to be a useful marker in the evaluation of acute appendicitis. In addition, CRP levels are increased proportionally with severity of appendiceal inflammation. But an increase in CRP levels alone is not sufficient to make the decision of the surgical intervention in the acute appendicitis. Despite the increase in the other inflammatory markers, PCT and D-dimer, in the acute appendicitis, the diagnostic value of CRP is higher than these two markers for the acute appendicitis. Future studies with larger sample size would be beneficial to evaluate the role of PCT, D-dimer and CRP in the acute appendicitis.

\section{Competing Interests}

The authors have declared that no competing interest exists.

\section{References}

1. Ivancević N, Radenković D, Bumbasirević V, Karamarković A, Jeremić V, Kalezić N, Vodnik T, Beleslin B, Milić N, Gregorić P, Zarković M. Procalcitonin in preoperative diagnosis of abdominal sepsis. Langenbecks Arch Surg. 2008;393:397-403.

2. Le Moullec JM, Jullienne A, Chenais J, Lasmoles F, Guliana JM, Milhaud G, Moukhtar MS. The complete sequence of human preprocalcitonin. FEBS Lett. 1984;13:93-7.

3. Assicot M, Gendrel D, Carsin H, Raymond J, Guilbaud J, Bohuon C. High serum procalcitonin concentrations in patients with sepsis and infection. Lancet. 1993;341:515- 518.

4. Maruna P, Frasko R, Gürlich R. Plasma procalcitonin in patients with ileus. Relations to other inflammatory parameters. Physiol Res. 2008;57:481-6.

5. Markogiannakis H, Memos N, Messaris E, Dardamanis D, Larentzakis A, Papanikolaou D, Zografos GC, Manouras A. Predictive value of procalcitonin for bowel ischemia and necrosis in bowel obstruction. Surgery. 2011 Mar;149(3):394-403.

6. Tillet WS, Francis T. Jr. Serological Reactions in pneumonia with a non-protein somatic fraction of pneumococcus. J Exp Med. 1930;52:561-71.

7. Eriksson S, Granstrom L. Laboratory tests in patients with suspected acute appendicitis. Acta Chir Scand. 1994;155:117-2.

8. Shakhatreh HS. The accuracy of C-reactive protein in the diagnosis of acute appendicitis compared with that of clinical diagnosis. Med Arh. 2000;54:109-10.

9. Colson M, Skinner KA, Dunnignton G. High negative appendectomy rates are no longer acceptable. Am J Surg 1997;174: 723-6.

10. Espinoza R, Ohmke J, García-Huidobro I, Guzmán S, Azocar M. Negative appendectomy: experience at a universty hospital. Rev Med Chil 1998; 126: 75-80.

11. Fingerhut A, Yahchouchy-Chouillard E, Etrenne JC. Appendicitis or nonspesific pain in the right iliac fossa. Rev Prot 2001; 51: 1654-6.

12. Agrawal CS, Adhikari S, Kumar M. Role of serum C-reactive protein and leukocyte count in the diagnosis of acute appendicitis in Nepalese population. Nepal Med Coll J. 2008; 10:11-5.

13. Grönroos JM, Forsström JJ, Irjala K, Nevalainen TJ. Phospholipase A2, C-reactive protein, and white blood cell count in the diagnosis of acute appendicitis. Clin Chem 1994;40:1757- 60.

14. Lycopoulou L, Mamoulakis C, Hantzi E, Demetriadis D, Antypas S, Giannaki M,Bakoula C, Chrousos G, Papassotiriou I. Serum amyloid A protein levels as a possible aid in the diagnosis of acute appendicitis in children. Clin Chem Lab Med 2005;43:49- 53.

15. Dalal I, Somekh E, Bilker-Reich A, Boaz M, Gorenstein A, Serour F. Serum and peritoneal inflammatory mediators in children with suspected acute appendicitis. Arch Surg 2005;140:169- 73.

16. Hatherill M, Jones G, Lim E, Tibby SM, Murdoch IA. Procalcitonin aids diagnosis of adrenocortical failure. Lancet 1997;350:1749-50.

17. Sand M, Trullen XV, Bechara FG, Pala XF, Sand D, Landgrafe G, Mann B. A prospective bicenter study investigating the diagnostic value of procalcitonin in patients with acute appendicitis. Eur Surg Res. 2009;43:291-7.

18. Kouame DB, Garrigue MA, Lardy H, Machet MC, Giraudeau B, Robert $\mathrm{M}$. Is procalcitonin able to help in pediatric appendicitis diagnosis? Ann Chir. 2005; 130:169-74.

19. Aslan A, Karaveli C, Ogunc D, Elpek O, Karaguzel G, Melikoglu M. Does noncomplicated acute appendicitis cause bacterial translocation? Pediatr Surg Int 2007; 23: 555-558.

20. Harrison KA, Haire WD, Pappas AA, Purnell GL, Palmer S, Holdeman KP, Fink LM, Dalrymple GV. Plasma D-Dimer: a useful tool for evaluating suspected pulmonary embolus. J Nucl Med 1993;34:896-8.

21. Meissner $\mathrm{MH}$, Zierler BK, Bergelin RO, Chandler WC, Manzo RA, Strandness DE Jr. Markers of plasma coagulation and fibrinolysis after acute deep venous thrombosis. J Vasc Surg 2000;32:870-80.

22. Bayes-Genis A, Mateo J, Santaló M, Oliver A, Guindo J, Badimon L. D-Dimer is an early diagnostic marker of coronary ischemia in patients with chest pain. Am Heart J 2000;140:379-84.

23. Engelman DT, Gabram SG, Allen L, Ens GE, Jacobs LM. Hypercoagulability following multiple trauma. World J Surg 1996;20:5-10. 
24. Raimondi P, Bongard O, de Moerloose P, Reber G, Waldvogel F, Bounameaux H. D-dimer plasma concentration in various clinical conditions: Implication for the use of this test in the diagnostic approach of venous thromboembolism. Thromb Res 1993;69:125-30.

25. Kurt Y, Akin ML, Demirbas S, Uluutku AH, Gulderen M, Avsar K, Celenk T. D-dimer in the early diagnosis of acute mesenteric ischemia secondary to arterial occlusion in rats. Eur Surg Res. 2005; 37 : 216-9.

26. Akyildiz HY, Sözüer E, Akcan A, Küçük C, Artis T, Biri I, Yilmaz N. The value of $\mathrm{D}$ - dimer test in the diagnosis of patients with nontraumatic acute abdomen. Ulus Travma Acil Cerrahi Derg. 2010; 16:22-6.

27. Mentes O, Eryilmaz M, Harlak A, Ozer T, Balkan M, Kozak O, Tufan T. D-dimer become a new diagnostic parameter for acute appendicitis? Am J Emerg Med.2009; 27:765-9.

28. al-Saigh AH. C-reactive protein in the differential diagnosis of the acute abdomen, especially acute appendicitis. J R Coll Surg Edinb 1992; 37:238-40.

29. Gurleyik E, Gurleyik G, Unalmiser S. Accuracy of serum C-reactive protein measurements in diagnosis of acute appendicitis compared with surgeon's clinical impression. Dis Colon Rectum 1995; 38: 1270-4.

30. Yang HR, Wang YC, Chung PK, Chen WK, Jeng LB, Chen RJ. Role of leukocyte count, neutrophil percentage, and C-reactive protein in the diagnosis of acute appendicitis in the elderly. Am Surg 2005; 71: 344-7.

31. Hallan S. Asberg A. The accuracy of C-reactive protein in diagnosing acute appendicitis- a meta-analysis. Scand J Clin Lab Invest 1997; 57: 373-80.

32. Grönroos JM, Grönroos P. Leucocyte count and C-reactive protein in the diagnosis of acute appendicitis. Br J Surg 1999;86:501-4.

33. Ortega-Deballon $\mathrm{P}$, Ruiz de Adana-Belbel JC, Hernández-Matías A, García-Septiem J, Moreno-Azcoita M. Usefulness of laboratory data in the management of right iliac fossa pain in adults. Dis Colon Rectum. 2008; 51:1093-9. 